\title{
Respiratory viral infections in children with asthma: do they matter and can we prevent them?
}

\author{
Hamid Ahanchian ${ }^{1,2}$, Carmen M Jones ${ }^{1}$, Yueh-sheng Chen ${ }^{1}$ and Peter D Sly ${ }^{1 *}$
}

\begin{abstract}
Background: Asthma is a major public health problem with a huge social and economic burden affecting 300 million people worldwide. Viral respiratory infections are the major cause of acute asthma exacerbations and may contribute to asthma inception in high risk young children with susceptible genetic background. Acute exacerbations are associated with decreased lung growth or accelerated loss of lung function and, as such, add substantially to both the cost and morbidity associated with asthma.

Discussion: While the importance of preventing viral infection is well established, preventive strategies have not been well explored. Good personal hygiene, hand-washing and avoidance of cigarette smoke are likely to reduce respiratory viral infections. Eating a healthy balanced diet, active probiotic supplements and bacterial-derived products, such as OM-85, may reduce recurrent infections in susceptible children. There are no practical anti-viral therapies currently available that are suitable for widespread use.
\end{abstract}

Summary: Hand hygiene is the best measure to prevent the common cold. A healthy balanced diet, active probiotic supplements and immunostimulant OM-85 may reduce recurrent infections in asthmatic children.

Keywords: Acute respiratory infections, Childhood asthma, Common cold, Acute exacerbations, Rhinovirus

\section{Background}

Asthma is a major public health problem with a huge social and economic burden affecting 300 million people worldwide [1]. Viral respiratory infections are the major cause of acute asthma exacerbations and contribute to asthma inception in high risk young children with susceptible genetic background. A history of wheeze associated with respiratory viral infections early in life is one of the major risk factors for the later development of asthma [2-7], together with sensitization to aeroallergens in early life and a family history of asthma and allergies, reflecting a genetic predisposition. Respiratory viral infections are also the principal cause of asthma exacerbations in children and adults [8-13]. However, the question of whether viral infections "select" susceptible hosts or whether viral infections may induce asthma de novo

\footnotetext{
*Correspondence: p.sly@uq.edu.au

'The Queensland Children's Medical Research Institute, The University of

Queensland, Brisbane, Australia

Full list of author information is available at the end of the article
}

by "damaging" airways is not settled. In other words, do viruses cause or simply unmask asthma?

\section{Viral infections and innate immune responses}

Respiratory viruses first infect nasal epithelial cells which triggers an antiviral response. This response is driven by type I $(\alpha / \beta)$ and III $(\lambda)$ interferons (IFN) that are induced following recognition of viral ribonucleic acid (RNA) by pattern recognition receptors (PRRs). Toll-like receptors (TLRs) are cell surface and endosomal PRRs, whilst the RNA helicase receptors (RIG-I and MDA-5) and NODlike receptors (NOD2), detect viral RNA in the cytoplasm. Signalling via the PRRs activates transcription factors (IRF-3, IRF-7, NF-kB), which lead to the production and secretion of type I and III IFN. The IFNs then bind to cell surface receptors to activate a separate pathway leading to the production of interferon stimulated genes (ISGs) which encode antiviral proteins that combat infection, as well as PRRs and transcriptional factors which further amplify IFN production. The respiratory syncytial virus (RSV), human meta-pneumovirus (hMPV) and human rhinovirus (HRV) are all single stranded RNA viruses but engage differently with cell signalling

\section{Biomed Central}


pathways. In airway epithelial cells RSV and hMPV RNA are primarily detected by RIG-I in the cytoplasm $[14,15]$. RSV can also be detected by NOD2 [16]. HRV is endocytosed by epithelial cells, and is therefore primarily detected by TLR3 in the endosome early in the infection process and by RIG-I and MDA-5 later in infection following upregulation of these PRRs [17]. The fusion (F) protein of RSV is recognised by TLR4 at the epithelial cell surface [18].

A successful antiviral response would see the infection limited to the upper airway, as is the case clinically with the majority of viral infections in healthy individuals. Should such a response be deficient, then predominantly upper-airway viral infections, such as HRV, may spread to the lower airways, causing lower respiratory symptoms and an exacerbation of asthma in predisposed individuals.

\section{Abnormal innate antiviral immunity in asthmatics}

While definitive data are yet to be produced, experimental HRV infections in adult volunteers initially suggested that asthmatics were more likely to develop lower respiratory infections (LRI) than healthy adults, i. e. less likely to be able to limit viral replication to the upper airways $[19,20]$. Subsequent in vitro infection of primary airway epithelial cells from asthmatic and healthy adults with HRV have demonstrated that asthmatic cells produce less IFN- $\beta$ [21] and IFN- $\lambda$ [22] making them potentially more susceptible to infection, slower to clear infection, and more susceptible to virus-induced cell cytotoxicity. Deficiencies in the IFN$\alpha$ response of peripheral blood mononuclear cells and plasmacytoid dendritic cells from asthmatic adults and children has also been observed, in these particular studies, in response to RSV, HRV $[14,15]$ and Influenza A [23]. It is likely that the overall impaired innate immune response of the asthmatic airway epithelium is a result of deficiencies in the antiviral response of both epithelial cells and immune cells. Childhood, especially infancy, is characterized by developmentally-regulated deficiencies in innate and adaptive immunity [24]. Such deficiencies are likely to increase the risk of viral LRI in children, especially in those at high risk for asthma and allergies.

\section{Viral infections in children with asthma}

Each year, at the end of summer, parents of asthmatic children are concerned about acute asthma exacerbations following a common cold, asking how to minimize the risk during the winter viral season. It is a valid concern as up to $70 \%$ of asthmatic children have an intermittent or wheeze which is mostly symptomatic after viral infections $[25,26]$. Asthmatics with exacerbationprone phenotype are susceptible to acute exacerbations requiring hospitalization or an unscheduled visit for medical attention. Major risk factors for acute exacerbations include previous acute exacerbation, allergy, young age, poorly controlled asthma, and, in particular, viral respiratory infections. Moreover, recent data suggests an interaction between allergies and viral infections occurs to increase the risk of asthma exacerbation [27]. Acute exacerbations are associated with decreased lung growth or accelerated loss of lung function and, as such, add substantially to both the cost and morbidity associated with asthma $[28,29]$. Viral respiratory infections are the main cause of asthma exacerbations in children (80$85 \%)$ and are a major risk factor for admission in hospital every autumn [30-32]. HRV are the most common viral agents [33]; Other respiratory tract viruses detected in children with an asthma exacerbation include RSV, influenza, coronavirus, hMPV, parainfluenza virus, adenovirus, and bocavirus [34-36]. Current drugs for the prevention and treatment of virus-induced exacerbation of asthma are poorly effective and novel alternative therapies are needed.

\section{Role of respiratory viral infections in asthma inception}

Much research interest has focused on the potential role respiratory viral infections play in the inception of asthma. It is well established that hospitalization for RSV bronchiolitis is a risk factor for asthma during childhood [37,38]. Epidemiological studies have shown an increased risk of asthma with LRI caused by HRV. In the Childhood Origin of Asthma (COAST) birth cohort study, wheezing with RSV (odds ratio [OR], 2.6), HRV (OR, 9.8), or both HRV and RSV (OR, 10) was associated with increased asthma risk at age six years [7]. The Childhood Asthma Study (CAS) in Perth, Australia showed that wheezing with HRV or RSV in the first year of life was a risk factor (OR, 2.5) for current wheeze at five years of age [4]. Infant birth about four months before the winter virus peak carried the highest risk of developing asthma compared with birth 12 months before the peak [39]. The risk of asthma is increased by severe LRI (sLRI), especially in the presence of allergic sensitization in early life $[4,25]$. There appears to be a synergistic interaction between viral infection and allergic sensitization, suggesting a "two hit" model for induction of persistent asthma. These data also provide a series of novel strategies for the primary prevention of asthma by prevention of either allergic sensitization or of sLRI in high risk children. This strategy is also supported in a study by Simoes et al. [40], in which the use of palivizumab to prevent RSV infection decreased the risk of recurrent wheezing in nonatopic premature infants.

The crucial period, with respect to asthma initiation, appears to be the first two to three years of life during 
which the growth and remodelling of lung and airways proceeds at maximum rates. Pulmonary inflammation resulting from atopy and sLRI occurring during this vulnerable time is hypothesized to perturb underlying tissue differentiation programs, resulting in deleterious long term effects on respiratory functions. As a result, there is widespread belief amongst the paediatric respiratory community that intervention measures that can lower the frequency and/or intensity of sLRI in early life amongst the high risk atopic subgroup of children are likely to be successful at preventing asthma. If successful, these strategies would have major implications for reducing the high impact of this chronic disease on the community $[17,41,42]$.

Recent studies using culture-independent techniques have challenged the long-held dogma that lungs are sterile and have demonstrated that a microbiota community exists in the lung [43-45]. The implications of these new data are not clear, however new concepts and more research is required. The resident microbiome is different in the presence of respiratory disease $[45,46]$; therefore interactions between respiratory viruses and the resident pulmonary microbiome are postulated. The pulmonary and gastrointestinal microbiota influence the immune system and interventional approaches (by bacterial immunostimulants, prebiotics and/or probiotics) to create a healthy gut and respiratory microbiota are potential strategies for the prevention of viral infections [45].

\section{Preventing viral infections by non-immunologic methods}

Children are important vectors for HRV transmission to family members particularly siblings $[47,48]$. HRV shedding peaks two to four days after infection and decreases sharply thereafter, although nasal samples can be positive for rhinovirus for up to five weeks after a symptomatic infection [49].

There are three ways of common cold transmission in children. First, inhalation of small particles aerosolized by coughing; second, large particle droplets from saliva expelled while sneezing; and third, self-inoculation of one's own conjunctivae or nasal mucosa after touching a person or object contaminated with the cold viruses. The first two methods are inefficient [50], while the third is the most important method of transmission. The mode of transmission could differ with age of the index case, duration of contact, and other factors. Moreover, there is some evidence that the daily activities of infected people can lead to the contamination of environmental surfaces with HRV e.g. light switches, telephone dial buttons and handsets [48].

Meticulous hand hygiene is the best measure to prevent the common cold; frequent hand washing and avoid touching one's nose and eyes [51-53]. The use of alcohol-based hand sanitizers is also effective [54,55]. The promotion of handwashing was associated with a 12$34 \%$ reduction in respiratory-tract infections and colds in child-care centres in the USA [56] Canada [57] and Australia [58] and a $21 \%$ decrease in absences due to respiratory illness in the school setting [56]. Hand hygiene campaigns were also successful in reducing absenteeism caused by influenza-like illnesses among schoolchildren in Egypt [59]. Similar programs within families would be expected to reduce transmission of HRV between family members.

A recent Cochrane review which included data from 67 randomised controlled trials and observational studies, investigated the effectiveness of physical interventions to reduce the spread of respiratory viruses. The authors concluded that respiratory virus spread can be reduced by hygiene measures (such as handwashing), especially around younger children and can reduce transmission from children to other family members [51]. Controversy still exists and a newly published study showed that an antiviral hand treatment used by adult volunteers, recruited from a university community, did not significantly reduce RV infection or RV-related common cold illnesses [60].

Asthmatic children should avoid close contact with people who have colds especially during the first three days of their illness. There is little evidence to support the effectiveness of face masks to reduce the risk of viral respiratory infections and consequently, the use of mask is generally not recommended for prevention of common cold [51,61].

\section{General immunologic strategies}

Immune function and anti-viral defenses have a number of components, both specific and non-specific. Asthmatic children can improve their immune function by following some simple advice including a healthy life style with regular exercise, a balanced diet, adequate sleep and avoiding environmental tobacco smoke, stress and unnecessary antibiotics.

\section{Exercise}

Exercise has anti-inflammatory effects and in the long term can protect the development of chronic diseases and obesity [62]. Regular exercise of moderate-intensity is associated with a reduced incidence of upper respiratory tract infection. However, long hours of intensive training appear to make children more susceptible to upper respiratory tract infections [63-65]. The recommended means of aerobic exercise is walking, with an optimal frequency of three to five days a week and an optimal duration of 20 to 30 minutes of continuous activity [66]. In a recent study, the IgA secretion rate was negatively correlated with the incidence of infections [67]. A recent randomized trial comparing meditation 
and exercise with wait-list control among adults aged 50 years and older found significant reductions in ARI illness [68].

\section{Diet}

Malnutrition is the most common cause of immune deficiency worldwide and a balanced diet is fundamental for a healthy immune system. Vitamin D deficiency has been associated with increased risk of infections, earlylife wheeze and reduced asthma control $[69,70]$. Vitamin A derivatives are involved in the regulation of the immune system and tissue inflammation as well as prevention of respiratory infections [71]. Zinc, selenium and other trace elements are necessary for function of both innate and adaptive immune function. A high intake of fruit and vegetables ensures adequate consumption of nutrients and antioxidants and appears to be beneficial for asthma. Although recent reviews have shown that zinc [72], garlic [73], Echinacea purpurea [74] or Ginseng [75] supplementation for several months may reduce cold incidence, there is insufficient evidence to recommend any vitamin or mineral supplementation in the management of asthmatic children without nutrient deficiency [76,77]. However, a large controlled trial showed Echinacea was ineffective in reducing infection rate or symptom severity of HRV infection in healthy young adult volunteers [78]. Vitamin $C$ supplementation failed to reduce the incidence of colds in the general population except in those exposed to short periods of extreme physical stress [79]. Finally, it is worth remembering that infants who are not breastfed have significantly higher risk of respiratory, gastrointestinal, and other infections, as breast milk is a biologically active substance containing antimicrobial and immunomodulatory elements [80-82].

\section{Sleep}

Sleep and the circadian system exert a regulatory influence on immune functions. Sleep deprivation can affect immune function in several ways including reduced natural killer cell activity, suppressed interleukin-2 production and increased levels of circulating proinflammatory cytokines $[83,84]$. There is also evidence for an enhanced susceptibility to the common cold and pneumonia with poor sleep efficiency $[85,86]$.

\section{Air pollution}

Air pollutants (nitrogen dioxide, ozone, particulate matter) and environmental tobacco smoke (ETS) have long been correlated with multiple adverse effects on the immune system and susceptibility to viral respiratory tract infections in children [87-90]. Studies in Europe and the United States have shown that $40 \%$ of children live with a smoker [34] and they have approximately twice the risk of contracting a serious respiratory tract infection in early life [91]. Cigarette smoking leads to a longer duration of cough, greater frequency of abnormal auscultatory findings during acute respiratory tract illness [92,93] and higher risk for severe exacerbations [94]. Urinary leukotriene E4 levels identify children exposed to ETS at high risk for asthma exacerbation [94].

\section{Specific immunologic strategies}

There is strong evidence that some pharmacological preparations can help prevent viral infection by specific effects on immune system. These results have been promising with a hope that using these strategies can attenuate the role of viruses in asthma inception.

\section{Probiotics and prebiotics}

Ancient physicians of the Middle East prescribed yogurt for curing disorders of the stomach, intestines and for stimulation of appetite. It is written in the old Persian Testament that "Abraham owed his longevity to the consumption of sour milk" [95]. The popularity of probiotics and intestinal microbiota significantly increased when the Nobel Prize-winning Russian scientist Eli Metchnikoff suggested in 1908 that the long life of Bulgarian peasants resulted from their consumption of fermented milk products [96]. The term probiotic, meaning for life, is used for live micro-organisms (typically of the bifidobacterium and lactobacillus species) administered in adequate amounts which confer a beneficial physiological effect on the host. Prebiotics are nutrients, in particular oligosaccharides, which foster the growth of probiotics in the colon. The term synbiotics is used when a product contains both probiotics and prebiotics [97].

Up to 100 trillion bacteria from different species colonize the human gut [98]. This microbiota participates in: host metabolism, vitamin synthesis, control of epithelial cell growth, protection from infectious microbes, and helps proper development and function of the immune system. There is constant cross-talk between microbiota and gut-associated lymphoid tissue (the largest lymphoid tissue of the human body which contains more than $60 \%$ of all body lymphocytes) to establish mucosal immune tolerance in the gut. Common mucosal immunity describes the phenomenon where immune cells, especially regulatory $\mathrm{T}$-cells, traffic to and influence responses at other mucosal surfaces, including the lungs [99]. Alteration in the microbiota composition (dysbiosis) results in immunological dysregulation that may underlie many human diseases such as inflammatory diseases [100], obesity [101], allergy [102] and autoimmunity [103].

Reduced bacterial diversity in the infant's gastrointestinal tract has been associated with an increased risk of 
allergic sensitization and allergic rhinitis but not asthma or atopic dermatitis [102]. In the first year of life, especially the first few weeks, the microbiota of the newborn is highly variable during this critical time of post-natal maturation of the immune system. Microbiota is shaped by genetic and environmental factors including: mode of delivery, neonates born by means of vaginal delivery are exposed to mothers gut, skin, and vaginal flora [104]; breast feeding and diet [105]; farm or urban living [106]; vitamin D status [107]; and antibiotic consumption $[98,108]$. This knowledge stimulated interest in the use of probiotics and prebiotics as the intentional introduction or encouragement of specific microbes to shape immune system development. Specifically, the microbiota can activate distinct tolerogenic dendritic cells in the gut and through this interaction can drive regulatory $\mathrm{T}$-cell differentiation that modulates both Th1 and Th2 responses inside and outside the gut [109-111]. Probiotics have been successfully used for the treatment of several gastrointestinal disorders (viral and antibiotic-associated diarrhea, inflammatory bowel disease) $[112,113]$. However, attempts to prevent or treat allergic disorders such as eczema, asthma and allergic rhinitis have had inconsistent results [99,109,114-116].

There are a growing number of clinical trials using probiotics for the prevention and management of respiratory infections. While the precise mechanisms are largely unknown, speculations include: probiotics compete against pathogens; increase the barrier function in respiratory epithelium; immunostimulatory effects by enhancing cellular immunity with increased activity of natural killer cells and macrophages in airways [117]. Probiotics reduce the frequency of gastrointestinal and respiratory tract infections in children who attend day care centres [118]. They have also been found to reduce the incidence of ventilator-associated pneumonia, respiratory infections in healthy and hospitalized children, and reduce the duration of common cold symptoms [119-122].

One study demonstrated that that daily probiotic supplementation for six winter months in children three to five years of age reduced the incidence of fever, coughing and rhinorrhea by $32-43 \%$ with no notable adverse events [123]. Probiotic combination with vitamins and minerals also reduced the duration and severity of common cold [124]. A recent Cochrane review of 14 randomised controlled trials showed that probiotics were better than placebo in reducing the number of episodes of acute upper respiratory infections (URIs) and reducing antibiotic use, while there were no differences in the mean duration of an episode and no increase in adverse events [125]. Probiotic foods such as probiotic milk or yogurt (functional foods) containing well-defined probiotic strains may reduce the risk of catching the common cold and represent a simple, safe, effective, available and affordable method for preventing respiratory infections in children [112,120,126-131].

Although there are several clinical trials that showed the preventive effect of probiotic, prebiotic [132] or synbiotics treatments [133] on respiratory infections, not all studies are positive with some failing to show any significant preventive effect [134]. To explain the different results in clinical trials, it is of particular importance to point out that the immunomodulatory capabilities of probiotics are strain-dependent. Difference in dosage, duration of intervention, population and environmental background may also affect the results. One major limitation in this field is that it is not possible to test just how "probiotic" a particular preparation is. Technical advances will be required before some of the apparent discrepant results of studies can be resolved.

\section{Immunostimulants}

Several immunostimulants, including herbal extracts, bacterial extracts, synthetic compounds, have been promoted as increasing the immune defences of the respiratory tract. A recent Cochrane review included data from 35 placebo-controlled trials including 4060 participants below the age of 18 years in which various types of "immunostimulants" were used to reduce acute respiratory tract infections, involving either upper or lower airways. The authors concluded that immunostimulants reduced the incidence of acute respiratory infections by $40 \%$ on average in susceptible children, but that trial quality was generally poor and a "high level of statistical heterogeneity was evident". A subgroup analysis focusing on bacterial immunostimulants, including OM85, produced similar results with lower statistical heterogeneity [135].

OM-85 BV (Broncho-Vaxom) is an immunostimulant extracted from eight common bacterial pathogens of the upper respiratory tract: Haemophilus influenzae, Diplococcus pneumoniae, Klebsiella pneumoniae and ozaenae, Staphylococcus aureus, Streptococcus pyogenes and viridans, Neisseria catarrhalis and has been used in several countries around the world for as long as 20 years [136]. Recent studies showed that OM-85 BV can reduce the number of acute respiratory infections by $25 \%$ to $50 \%$ compared with placebo in children with a history of recurrent infection [137]. Of particular interest, Razi et al. showed that children between the age one and six years with recurrent wheezing who were given OM-85 BV had a $40 \%$ reduction in the rates of wheezing over the subsequent 12 months, compared to placebo $(\mathrm{p}<0.001)$. In addition, the duration of each wheezing attack was two days shorter in the group given OM-85 BV than in the group given placebo $(p=0.001)$ [138]. 
Again, direct evidence of the mechanisms involved are lacking from human studies. However, recent data from rodents shows that baseline regulatory $\mathrm{T}$ lymphocyte activity in the airways can be boosted by microbe-derived stimulation of the gut [139]. Bacterial immunostimulants were also shown to enhance innate immunity (i.e. intensification of phagocytosis) and adaptive immunity [140].

\section{Interferons}

As discussed above, evidence exists for an impaired innate immune response to respiratory viral infections in asthmatics [141]. Entry of rhinovirus into normal epithelial cells initiates a vigorous innate immune response with IFN- $\beta$ secretion and apoptosis induction. In asthma, IFN- $\beta$ and IFN- $\lambda$ responses are impaired, resulting in viral replication, cell cytotoxicity, enhanced virion shedding and increased susceptibility to common cold $[17,142]$. Epithelial cells of asthmatic patients responded to exogenous treatment with IFN- $\beta$ exhibiting reduced rhinovirus release (Cakebread, Xu et al. 2011; Jackson, Sykes et al. 2011). If the proposed deficiency of type I and III contribute to asthma exacerbations [21,22,143], correcting this deficiency with exogenous interferons would be a logical approach. The advantages of interferon application include the broad spectrum of activity with low risk of resistance development [47]. Prophylactic intranasal recombinant IFN- $\alpha$ and IFN- $\beta$ have been shown to be effective against rhinovirus infection in humans [144-146]. The results of these clinical trials are awaited with interest $[147,148]$. However, the systemic symptoms associated with severe viral infections, e.g. influenza, are associated with interferons, so careful dosing may be required. Considering the occurrence of the local side effects, neutropenia and cost, the use of long-term prophylaxis with daily, intranasal administration of interferons is not feasible [144]. However, randomized clinical trials using similar strategies are currently underway in adults with chronic respiratory disease and the results are keenly awaited.

\section{Vitamin D}

Vitamin D deficiency is a common worldwide problem [149-150]. Beside importance for bone health, vitamin D plays an important role in adequate function of both the innate and adaptive immune systems including development of dendritic cells and regulatory $\mathrm{T}$ lymphocytes $[151,152]$ production of antimicrobial proteins by airway epithelium [153], modifying the effect of intestinal flora on inflammatory disorders [107], and modulation of the inflammatory response to viral infections [154]. Recent reports suggest that vitamin $\mathrm{D}$ might play a role in the recent increase in allergic disease [155-157]. Vitamin D insufficiency has been associated with a higher incidence of respiratory tract infection, wheezing illness in children
[158], reduced asthma control [159], emergency department visits, severe asthma exacerbations and hospitalizations [70,160]. In a recent study of 48 children from five to 18 years of age, with newly diagnosed asthma, vitamin D supplementation during the northern hemisphere winter months (September to July) prevented declining serum concentrations of $25(\mathrm{OH}) \mathrm{D}$ and reduced the risk of asthma exacerbation triggered by acute respiratory tract infections [161].

\section{Macrolides}

Macrolides possess anti-inflammatory and immunomodulatory properties extending beyond their antibacterial activity [162]. Indeed, they can attenuate pro-inflammatory cytokine production by bronchial epithelial cells, neutrophils and macrophages that may contribute to clinical improvement in many patients with chronic airway inflammation [163-165]. Azithromycin has anti-rhinoviral activity and can reduce HRV replication and release by increasing interferon production from epithelial cells $[42,166,167]$. Macrolide antibiotics inhibit RSV infection in human airway epithelial cells [168]. A three weeks treatment with clarithromycin in RSV bronchiolitis had statistically significant effects on hospital length of stay and rate of readmission to the hospital within six months after discharge [169]. However, direct evidence of macrolides preventing respiratory viral infection in children is lacking.

\section{Anti-viral therapies}

As the majority of respiratory viral infections in young children are caused by HRV or RSV, we will briefly discuss anti-viral strategies to prevent HRV or RSV infections in asthmatic children. Because there are more than 100 serotypes of HRV, antiviral drugs are considered to be more effective than vaccination. Antiviral agents have been designed to inhibit rhinovirus attachment, entry to the cell, viral uncoating, and RNA and protein synthesis [47]. Table 1 shows how intervention strategies can be targeted to various steps in the infective process.

\section{Rhinovirus structure}

HRV has the icosahedrally shaped capsid formed by 60 identical copies of viral capsid structural proteins VP1-4. The capsid protects the single-stranded, positive sense RNA genome. While HRV-A and -B most often induce a self-limited upper respiratory infection, the recently discovered HRV-C was associated with sLRIs in infants, bronchiolitis, and asthma exacerbations in children $[170,171]$.

\section{Prevention of attachment, entry and uncoating}

HRV deposits on nasal or conjunctival mucosa and is transported to the posterior nasopharynx by mucociliary 
Table 1 The processes of rhinoviral infection and preventive strategies

\begin{tabular}{|c|c|}
\hline Process & Preventive strategies \\
\hline Rhinoviral transmission & Hand hygiene, isolation \\
\hline \multirow[t]{2}{*}{$\begin{array}{l}\text { Attachment to } \\
\text { respiratory epithelium }\end{array}$} & $\begin{array}{l}\text { HRV neutralizing antibodies, } \\
\text { anti-receptor antibodies }\end{array}$ \\
\hline & $\begin{array}{l}\text { Second generation antihistamines, } \\
\text { zinc vaccines }\end{array}$ \\
\hline $\begin{array}{l}\text { Entry, RNA and } \\
\text { protein synthesis }\end{array}$ & $\begin{array}{l}\text { Anti-rhinoviral therapies } \\
\text { (Pleconaril, Ruprintrivir) }\end{array}$ \\
\hline Enhancing immunity & $\begin{array}{l}\text { Balanced diet, interferons, } \\
\text { immunostimulants, } \\
\text { probiotics, breast milk, } \\
\text { Echinacea, garlic, zinc, ginseng }\end{array}$ \\
\hline
\end{tabular}

action of epithelial cells [172]. The so-called major group of HRV uses intercellular adhesion molecule-1 (ICAM1 ) as their receptor [173] and the minor group attach to low density lipoprotein (LDL) receptor and very-LDL (VLDL) receptors on epithelial cells in the adenoid area to bind and enter cells $[174,175]$. Viral attachment can be prevented by specific anti-HRV neutralizing antibodies, anti-receptor antibodies and soluble receptor molecules.

Endothelial cells express histamine receptors and increased adhesion molecule expression, such as ICAM1 , was demonstrated by histamine infusion. Second-generation H1-antihistamines decrease expression of ICAM-1 on cultured bronchial epithelial cells [176]. Zinc may also act as an antiviral agent by reducing ICAM-1 levels [177].

The monoclonal antibody to the cellular ICAM-1 was not effective. CFY196 (Coldsol) is a nasal spray multivalent Fab fusion proteins against ICAM-1 with a better avidity and in vitro potency against HRV [178]. Tremacamra, a soluble intercellular adhesion molecule 1 reduced the severity of experimental rhinovirus infection [179]. Pleconaril, an orally administered antiviral drug, acts by binding to a hydrophobic pocket in viral protein 1 , and stabilizes the protein capsid so that the virus cannot release its RNA genome into the target cell. Outcomes of clinical trials with pleconaril have revealed mixed results and new compounds are currently being developed [180].

\section{Prevent RNA and protein synthesis}

Despite extensive research, no agent has been approved for prevention and/or therapy of rhinovirus-induced diseases so far. Ruprintrivir selectively inhibits HRV 3C protease and shows potent, broad-spectrum anti-HRV activity in vitro. Ruprintrivir nasal spray ( $2 \%$ solution) prophylaxis reduced the proportion of subjects with positive viral culture by $26 \%$ and reduce viral titers, but did not decrease the frequency of colds [181]. HRV
RNA synthesis during replication can be blocked by deoxyribozymes [182], morpholino oligomers [183], and small interfering ribonucleic acids [184]. The novel antiviral therapies that have been discovered recently, may one day add significantly to the armamentarium of antiviral agents, against respiratory viral infections in asthmatic children.

\section{Monoclonal antibodies}

Maternally-derived RSV neutralizing antibodies help to protect infants against RSV hospitalization [185]. Palivizumab, a humanised monoclonal antibody against the RSV fusion protein is effective against RSV and wheezing in children and reduces hospitalization in high-risk individuals $[185,187]$. RSV prophylaxis with palivizumab significantly reduced the relative risk of subsequent recurrent wheezing in nonatopic premature infants [40]. Motavizumab is another monoclonal antibody against RSV, with an approximately 20 -fold increase in ability to neutralize RSV and 100 fold increase in ability to reduce viral titers compared to palivizumab $[188,189]$. Motavizumab was also found to be superior to palivizumab in reducing outpatient medically attended lower respiratory illness by $50 \%$ [190].

\section{Vaccination}

Vaccination against HRV and RSV have been in development for quite some time, but there are no safe and effective vaccines at present $[33,191]$. High rates of exposure to

Table 2 Summary of interventions to prevent rhinoviral infection in asthmatic children

\begin{tabular}{ll}
\hline Effectiveness & Interventions \\
\hline Most likely to be beneficial & Hand Hygiene \\
& Immunostimulants (OM-85) \\
& Probiotics (specific strains), \\
& Prebiotics and Synbiotics \\
& Breast milk \\
& Regular exercise, balanced diet, \\
& adequate sleep, low psychological \\
Likely to be beneficial & Press \\
& environmention of air pollutions and \\
& Second generation of antihistamines \\
& Monoclonal antibodies: \\
& Anti lgE, Anti IL-5 \\
& Vitamin D, Vitamin A \\
& Garlic, zinc, ginseng \\
& Interferons \\
& Montelukast \\
Unknown effectiveness & Vitamin C \\
& Macrolides \\
& Echinacea \\
& Antiviral drugs \\
Unlikely to be beneficial & Mask \\
Laccination & Antibiotics \\
Intensive exercise
\end{tabular}


viruses in early life, presence of more than 100 serotypes of HRV, the presence of maternal antibodies, the risk of vaccine induced disease and relative immaturity of the infant immune system make effective vaccination difficult $[186,192,193]$.

\section{Discussion}

Respiratory viral infections are major contributors to the global burden imposed by asthma. In early life, they contribute to the inception of asthma and are responsible for most of the acute exacerbations for asthma in childhood. While the debate is not completely settled, children at high risk of developing asthma and those with established asthma may be at increased risk of acquiring respiratory viral infections and may be less able to contain these to the upper airway. Several simple general strategies can be used to help prevent respiratory viral infections in asthmatic children (Table 2), with good personal hygiene, hand-washing and avoidance of cigarette smoke likely to reduce respiratory viral infections. General immuno-stimulatory strategies, such as eating a healthy balanced diet, active probiotic supplements and bacterial-derived products, e.g. OM-85, may reduce recurrent infections in susceptible children.

\section{Summary}

While research continues on specific anti-viral therapies, including vaccination, there are no currently available practical therapies that are suitable for widespread use. The role of preventative strategies in primary prevention of asthma in high risk children is of considerable academic interest and a number of studies are currently in the pipeline. The results are awaited with interest.

\section{Abbreviations \\ IFN: Interferon; PRRs: Pattern recognition receptors; TLRs: Toll-like receptors; HRV: Human rhinovirus; RSV: Respiratory syncytial virus; hMPV: Human meta- pneumovirus; LRI: Lower respiratory infections; SLRI: Severe lower respiratory infections; ETS: Environmental tobacco smoke; ICAM-1: Intercellular adhesion molecule-1.}

\section{Competing interests}

The authors declare they have no competing interests.

\section{Author's contribution}

$\mathrm{HA}$ and PDS conceived and designed the review. All authors reviewed the articles, abstracted data, and participated in the data synthesis. HA, PDS, YSC drafted the current manuscript, with critical review by PDS and CMJ. All authors contributed, read and approved the final manuscript.

\section{Acknowledgement}

The authors wish to acknowledge Dr. Catherine Gangell for reviewing the manuscript.

\section{Author details}

'The Queensland Children's Medical Research Institute, The University of Queensland, Brisbane, Australia. ${ }^{2}$ Allergy research Center, Mashhad University of Medical Sciences, Mashhad, Iran.
Received: 24 April 2012 Accepted: 3 September 2012

Published: 13 September 2012

\section{References}

1. Masoli M, Fabian D, Holt S, Beasley R: The global burden of asthma: executive summary of the GINA Dissemination Committee report. Allergy 2004, 59(5):469-478

2. Stein RT, Sherrill D, Morgan WJ, Holberg CJ, Halonen M, Taussig LM, Wright AL, Martinez FD: Respiratory syncytial virus in early life and risk of wheeze and allergy by age 13 years. Lancet 1999, 354(9178):541-545.

3. Sigurs N, Bjarnason R, Sigurbergsson F, Kjellman B: Respiratory syncytial virus bronchiolitis in infancy is an important risk factor for asthma and allergy at age 7. Am J Respir Crit Care Med 2000, 161(5):1501-1507.

4. Kusel MM, de Klerk NH, Kebadze T, Vohma V, Holt PG, Johnston SL, Sly PD: Early-life respiratory viral infections, atopic sensitization, and risk of subsequent development of persistent asthma. J Allergy Clin Immunol 2007, 119(5):1105-1110.

5. Sly PD, Kusel M, Holt PG: Do early-life viral infections cause asthma? J Allergy Clin Immunol 2010, 125(6):1202-1205.

6. Lemanske RF Jr, Jackson DJ, Gangnon RE, Evans MD, Li Z, Shult PA, Kirk CJ, Reisdorf E, Roberg KA, Anderson EL, et al: Rhinovirus illnesses during infancy predict subsequent childhood wheezing. J Allergy Clin Immunol 2005, 116(3):571-577.

7. Jackson DJ, Gangnon RE, Evans MD, Roberg KA, Anderson EL, Pappas TE, Printz MC, Lee WM, Shult PA, Reisdorf E, et al: Wheezing rhinovirus illnesses in early life predict asthma development in high-risk children. Am J Respir Crit Care Med 2008, 178(7):667-672.

8. Nicholson KG, Kent J, Ireland DC: Respiratory viruses and exacerbations of asthma in adults. BMJ 1993, 307(6910):982-986.

9. Mallia P, Johnston SL: How viral infections cause exacerbation of airway diseases. Chest 2006, 130(4):1203-1210.

10. Kling S, Donninger H, Williams Z, Vermeulen J, Weinberg E, Latiff K, Ghildyal R, Bardin P: Persistence of rhinovirus RNA after asthma exacerbation in children. Clin Exp Allergy 2005, 35(5):672-678.

11. Murray CS, Poletti G, Kebadze T, Morris J, Woodcock A, Johnston SL, Custovic A: Study of modifiable risk factors for asthma exacerbations: virus infection and allergen exposure increase the risk of asthma hospital admissions in children. Thorax 2006, 61(5):376-382.

12. Heymann PW, Carper HT, Murphy DD, Platts-Mills TA, Patrie J, McLaughlin AP, Erwin EA, Shaker MS, Hellems M, Peerzada J, et al: Viral infections in relation to age, atopy, and season of admission among children hospitalized for wheezing. J Allergy Clin Immunol 2004, 114(2):239-247.

13. Wark PA, Johnston SL, Moric I, Simpson JL, Hensley MJ, Gibson PG: Neutrophil degranulation and cell lysis is associated with clinical severity in virus-induced asthma. Eur Respir J 2002, 19(1):68-75.

14. Holtzman MJ, Byers DE, Benoit LA, Battaile JT, You Y, Agapov E, Park C, Grayson MH, Kim EY, Patel AC: Immune pathways for translating viral infection into chronic airway disease. Adv Immunol 2009, 102:245-276.

15. Holtzman MJ, Patel DA, Zhang Y, Patel AC: Host epithelial-viral interactions as cause and cure for asthma. Curr Opin Immunol 2011, 23(4):487-494.

16. Holgate ST: The epithelium takes centre stage in asthma and atopic dermatitis. Trends Immunol 2007, 28(6):248-251.

17. Holgate ST: The sentinel role of the airway epithelium in asthma pathogenesis. Immunol Rev 2011, 242(1):205-219.

18. Ziegler SF, Artis D: Sensing the outside world: TSLP regulates barrier immunity. Nat Immunol 2010, 11(4):289-293.

19. Fraenkel DJ, Bardin PG, Sanderson G, Lampe F, Johnston SL, Holgate ST: Lower airways inflammation during rhinovirus colds in normal and in asthmatic subjects. Am J Respir Crit Care Med 1995, 151(3 Pt 1):879-886.

20. Bochkov YA, Hanson KM, Keles S, Brockman-Schneider RA, Jarjour NN, Gern JE: Rhinovirus-induced modulation of gene expression in bronchial epithelial cells from subjects with asthma. Mucosal Immunol 2010, 3(1):69-80.

21. Wark PA, Johnston SL, Bucchieri F, Powell R, Puddicombe S, Laza-Stanca V, Holgate ST, Davies DE: Asthmatic bronchial epithelial cells have a deficient innate immune response to infection with rhinovirus. J Exp Med 2005, 201(6):937-947.

22. Contoli M, Message SD, Laza-Stanca V, Edwards MR, Wark PA, Bartlett NW, Kebadze T, Mallia P, Stanciu LA, Parker HL, et al: Role of deficient type III interferon-lambda production in asthma exacerbations. Nat Med 2006, 12(9):1023-1026 
23. Gill MA, Bajwa G, George TA, Dong CC, Dougherty II, Jiang N, Gan VN, Gruchalla RS: Counterregulation between the FcepsilonRI pathway and antiviral responses in human plasmacytoid dendritic cells. J Immunol 2010, 184(11):5999-6006.

24. Tulic MK, Hurrelbrink RJ, Prele CM, Laing IA, Upham JW, Le Souef P, Sly PD, Holt PG: TLR4 polymorphisms mediate impaired responses to respiratory syncytial virus and lipopolysaccharide. J Immunol 2007 179(1):132-140.

25. Holt PG, Sly PD: Interaction between adaptive and innate immune pathways in the pathogenesis of atopic asthma: operation of a lung/ bone marrow axis. Chest 2011, 139(5):1165-1171.

26. Hales BJ, Chai LY, Elliot CE, Pearce $\sqcup$, Zhang G, Heinrich TK, Smith WA, Kusel MM, Holt PG, Sly PD, et al: Antibacterial antibody responses associated with the development of asthma in house dust mite-sensitised and non-sensitised children. Thorax 2011, 67(4):321-327.

27. Jackson DJ, Sykes A, Mallia P, Johnston SL: Asthma exacerbations: origin, effect, and prevention. J Allergy Clin Immunol 2011, 128(6):1165-1174.

28. O'Byrne PM, Pedersen S, Lamm CJ, Tan WC, Busse WW: Severe exacerbations and decline in lung function in asthma. Am J Respir Crit Care Med 2009, 179(1):19-24.

29. Weiss ST, Van NML, Zeiger RS: Relationship between increased airway responsiveness and asthma severity in the childhood asthma management program. Am J Respir Crit Care Med 2000, 162(1):50-56.

30. Sears MR, Johnston NW: Understanding the September asthma epidemic. J Allergy Clin Immunol 2007, 120(3):526-529.

31. Forno E, Celedon JC: Predicting asthma exacerbations in children. Curr Opin Pulm Med 2012, 18(1):63-69.

32. Busse WW, Lemanske RF Jr, Gern JE: Role of viral respiratory infections in asthma and asthma exacerbations. Lancet 2010, 376(9743):826-834.

33. Jackson DJ, Johnston SL: The role of viruses in acute exacerbations of asthma. J Allergy Clin Immunol 2010, 125(6):1178-1187. quiz 1188-1179.

34. Jackson DJ, Sykes A, Mallia P, Johnston SL: Asthma exacerbations: origin, effect, and prevention. J Allergy Clin Immunol 2011, 128(6):1165-1174.

35. Johnston NW, Johnston SL, Duncan JM, Greene JM, Kebadze T, Keith PK, Roy M, Waserman S, Sears MR: The September epidemic of asthma exacerbations in children: a search for etiology. J Allergy Clin Immunol 2005, 115(1):132-138.

36. Dulek DE, Peebles RS Jr: Viruses and asthma. Biochim Biophys Acta 2011, 1810(11):1080-1090.

37. Wu P, Hartert TV: Evidence for a causal relationship between respiratory syncytial virus infection and asthma. Expert Rev Anti Infect Ther 2011, 9(9):731-745.

38. Gern JE: Rhinovirus and the initiation of asthma. Curr Opin Allergy Clin Immunol 2009, 9(1):73-78.

39. Wu P, Dupont WD, Griffin MR, Carroll KN, Mitchel EF, Gebretsadik T, Hartert TV: Evidence of a causal role of winter virus infection during infancy in early childhood asthma. Am J Respir Crit Care Med 2008, 178(11):1123-1129.

40. Simoes EA, Carbonell-Estrany X, Rieger $\mathrm{CH}$, Mitchell I, Fredrick L, Groothuis JR, Palivizumab Long-Term Respiratory Outcomes Study G: The effect of respiratory syncytial virus on subsequent recurrent wheezing in atopic and nonatopic children. J Allergy Clin Immunol 2010, 126(2):256-262.

41. Holt PG, Upham JW, Sly PD: Contemporaneous maturation of immunologic and respiratory functions during early childhood: implications for development of asthma prevention strategies. J Allergy Clin Immunol 2005, 116(1):16-24. quiz 25.

42. Jackson DJ: The role of rhinovirus infections in the development of early childhood asthma. Curr Opin Allergy Clin Immunol 2010, 10(2):133-138

43. Huang YJ, Lynch SV: The emerging relationship between the airway microbiota and chronic respiratory disease: clinical implications. Expert Rev Respir Med 2011, 5(6):809-821.

44. Brar T, Nagaraj S, Mohapatra S: Microbes and asthma: the missing cellular and molecular links. Curr Opin Pulm Med 2012, 18(1):14-22.

45. Bisgaard H, Hermansen MN, Bonnelykke K, Stokholm J, Baty F, Skytt NL, Aniscenko J, Kebadze T, Johnston SL: Association of bacteria and viruses with wheezy episodes in young children: prospective birth cohort study. BMJ 2010, 341:c4978.

46. Hishiki H, Ishiwada N, Fukasawa C, Abe K, Hoshino T, Aizawa J, Ishikawa N, Kohno $Y$ : Incidence of bacterial coinfection with respiratory syncytial virus bronchopulmonary infection in pediatric inpatients. $J$ Infect Chemother 2011, 17(1):87-90.

47. Rollinger JM, Schmidtke M: The human rhinovirus: human-pathological impact, mechanisms of antirhinoviral agents, and strategies for their discovery. Med Res Rev 2011, 31(1):42-92.

48. Peltola V, Waris M, Osterback R, Susi P, Ruuskanen O, Hyypia T: Rhinovirus transmission within families with children: incidence of symptomatic and asymptomatic infections. J Infect Dis 2008, 197(3):382-389.

49. Jartti T, Lehtinen P, Vuorinen T, Koskenvuo M, Ruuskanen O: Persistence of rhinovirus and enterovirus RNA after acute respiratory illness in children. J Med Virol 2004, 72(4):695-699.

50. Pappas DE, Hendley JO: The common cold and decongestant therapy. Pediatr Rev 2011, 32(2):47-54. quiz 55.

51. Jefferson T, Del Mar CB, Dooley L, Ferroni E, Al-Ansary LA, Bawazeer GA, van Driel ML, Nair S, Jones MA, Thorning S, et al: Physical interventions to interrupt or reduce the spread of respiratory viruses. Cochrane Database Syst Rev 2011, (7):CD006207.

52. Stewardson A, Allegranzi B, Sax H, Kilpatrick C, Pittet D: Back to the future: rising to the Semmelweis challenge in hand hygiene. Future Microbiol 2011, 6(8):855-876

53. Luby SP, Agboatwalla M, Feikin DR, Painter J, Billhimer W, Altaf A, Hoekstra RM: Effect of handwashing on child health: a randomised controlled trial. Lancet 2005, 366(9481):225-233.

54. Lee GM, Salomon JA, Friedman JF, Hibberd PL, Ross-Degnan D, Zasloff E, Bediako S, Goldmann DA: Illness transmission in the home: a possible role for alcohol-based hand gels. Pediatrics 2005, 115(4):852-860.

55. Sandora TJ, Taveras EM, Shih MC, Resnick EA, Lee GM, Ross-Degnan D, Goldmann DA: A randomized, controlled trial of a multifaceted intervention including alcohol-based hand sanitizer and hand-hygiene education to reduce illness transmission in the home. Pediatrics 2005, 116(3):587-594.

56. Master D, Hess Longe SH, Dickson H: Scheduled hand washing in an elementary school population. Fam Med 1997, 29(5):336-339.

57. Carabin H, Gyorkos TW, Soto JC, Joseph L, Payment P, Collet JP: Effectiveness of a training program in reducing infections in toddlers attending day care centers. Epidemiology 1999, 10(3):219-227.

58. Roberts L, Smith W, Jorm L, Patel M, Douglas RM, McGilchrist C: Effect of infection control measures on the frequency of upper respiratory infection in child care: a randomized, controlled trial. Pediatrics 2000 105(4 Pt 1):738-742.

59. Talaat M, Afifi S, Dueger E, El-Ashry N, Marfin A, Kandeel A, Mohareb E, ElSayed $\mathrm{N}$ : Effects of hand hygiene campaigns on incidence of laboratoryconfirmed influenza and absenteeism in schoolchildren, Cairo, Egypt. Emerg Infect Dis 2011, 17(4):619-625.

60. Turner RB, Fuls JL, Rodgers ND, Goldfarb HB, Lockhart LK, Aust LB: A randomized trial of the efficacy of hand disinfection for prevention of rhinovirus infection. Clinical infectious diseases: an official publication of the Infectious Diseases Society of America 2012, 54(10):1422-1426.

61. Cowling BJ, Zhou Y, Ip DK, Leung GM, Aiello AE: Face masks to prevent transmission of influenza virus: a systematic review. Epidemiol Infect 2010, 138(4):449-456.

62. Gleeson M, Bishop NC, Stensel DJ, Lindley MR, Mastana SS, Nimmo MA: The antiinflammatory effects of exercise: mechanisms and implications for the prevention and treatment of disease. Nat Rev Immunol 2011, 11(9):607-615.

63. Matthews CE, Ockene IS, Freedson PS, Rosal MC, Merriam PA, Hebert JR: Moderate to vigorous physical activity and risk of upper-respiratory tract infection. Med Sci Sports Exerc 2002, 34(8):1242-1248.

64. Nieman DC, Henson DA, Austin MD, Sha W: Upper respiratory tract infection is reduced in physically fit and active adults. $\mathrm{Br} J$ Sports Med 2011, 45(12):987-992.

65. Fahlman MM, Engels HJ: Mucosal IgA and URTI in American college football players: a year longitudinal study. Med Sci Sports Exerc 2005 37(3):374-380.

66. Lucas SR, Platts-Mills TA: Physical activity and exercise in asthma: relevance to etiology and treatment. J Allergy Clin Immunol 2005, 115(5):928-934.

67. Gleeson M, Bishop N, Oliveira M, McCauley T, Tauler P, Muhamad AS: Respiratory infection risk in athletes: association with antigen-stimulated IL-10 production and salivary IgA secretion. Scand J Med Sci Sports 2011, 22(3):410-417

68. Barrett B, Hayney MS, Muller D, Rakel D, Ward A, Obasi CN, Brown R, Zhang Z, Zgierska A, Gern J, et al: Meditation or exercise for preventing acute 
respiratory infection: a randomized controlled trial. Ann Fam Med 2012, 10(4):337-346.

69. Brehm JM, Celedon JC, Soto-Quiros ME, Avila L, Hunninghake GM, Forno E, Laskey D, Sylvia JS, Hollis BW, Weiss ST, et al: Serum vitamin D levels and markers of severity of childhood asthma in Costa Rica. Am J Respir Crit Care Med 2009, 179(9):765-771.

70. Brehm JM, Schuemann B, Fuhlbrigge AL, Hollis BW, Strunk RC, Zeiger RS, Weiss ST, Litonjua AA: Serum vitamin D levels and severe asthma exacerbations in the Childhood Asthma Management Program study. J Allergy Clin Immunol 2010, 126(1):52-58. e55.

71. Issazadeh-Navikas S, Teimer R, Bockermann R: Influence of dietary components on regulatory T cells. Mol Med 2011, 18(1):95-110.

72. Singh M, Das RR: Zinc for the common cold. Cochrane Database Syst Rev 2011, (2):CD001364.

73. Lissiman E, Bhasale AL, Cohen M: Garlic for the common cold. Cochrane Database Syst Rev 2009, (3):CD006206

74. Linde K, Barrett B, Wolkart K, Bauer R, Melchart D: Echinacea for preventing and treating the common cold. Cochrane Database Syst Rev 2006, (1):CD000530.

75. Seida JK, Durec T, Kuhle S: North American (Panax quinquefolius) and Asian Ginseng (Panax ginseng) preparations for prevention of the common cold in healthy adults: a systematic review. Evid Based Complement Alternat Med 2011, 2011:282151.

76. McCloud E, Papoutsakis C: A medical nutrition therapy primer for childhood asthma: current and emerging perspectives. J Am Diet Assoc 2011, 111(7):1052-1064.

77. Levy ML, Thomas M, Small I, Pearce L, Pinnock H, Stephenson P: Summary of the 2008 BTS/SIGN British guideline on the management of asthma. Prim Care Respir J 2009, 18(Suppl 1):S1-S16.

78. Turner RB, Bauer R, Woelkart K, Hulsey TC, Gangemi JD: An evaluation of Echinacea angustifolia in experimental rhinovirus infections. $N$ Engl J Med 2005, 353(4):341-348.

79. Douglas RM, Hemila H, Chalker E, Treacy B: Vitamin C for preventing and treating the common cold. Cochrane Database Syst Rev 2007, (3):CD000980.

80. Labbok MH, Clark D, Goldman AS: Breastfeeding: maintaining an irreplaceable immunological resource. Nat Rev Immunol 2004, 4(7):565-572.

81. Abrahams SW, Labbok MH: Breastfeeding and otitis media: a review of recent evidence. Curr Allergy Asthma Rep 2011, 11(6):508-512.

82. Torres-Borrego J, Moreno-Solis G, Molina-Teran AB: Diet for the prevention of asthma and allergies in early childhood: much ado about something? Allergol Immunopathol (Madr) 2012, 40(4):244-252.

83. Besedovsky L, Lange T, Born J: Sleep and immune function. Pflugers Arch 2012, 463(1):121-137.

84. Lange T, Dimitrov S, Born J: Effects of sleep and circadian rhythm on the human immune system. Ann N Y Acad Sci 2010, 1193:48-59.

85. Cohen S, Doyle WJ, Alper CM, Janicki-Deverts D, Turner RB: Sleep habits and susceptibility to the common cold. Arch Intern Med 2009, 169(1):62-67.

86. Patel SR, Malhotra A, Gao X, Hu FB, Neuman MI, Fawzi WW: A prospective study of sleep duration and pneumonia risk in women. Sleep 2012, 35(1):97-101.

87. Treyster Z, Gitterman B: Second hand smoke exposure in children: environmental factors, physiological effects, and interventions within pediatrics. Rev Environ Health 2011, 26(3):187-195.

88. Huttunen $\mathrm{R}$, Heikkinen T, Syrjanen J: Smoking and the outcome of infection. J Intern Med 2011, 269(3):258-269.

89. Ciencewicki J, Jaspers I: Air pollution and respiratory viral infection. Inhal Toxicol 2007, 19(14):1135-1146.

90. Rabinovitch N, Silveira L, Gelfand EW, Strand M: The response of children with asthma to ambient particulate is modified by tobacco smoke exposure. Am J Respir Crit Care Med 2011, 184(12):1350-1357.

91. Li JS, Peat JK, Xuan W, Berry G: Meta-analysis on the association between environmental tobacco smoke (ETS) exposure and the prevalence of lower respiratory tract infection in early childhood. Pediatr Pulmonol 1999, 27(1):5-13.

92. Aronson MD, Weiss ST, Ben RL, Komaroff AL: Association between cigarette smoking and acute respiratory tract illness in young adults. Jama 1982, 248(2):181-183.

93. Venarske DL, Busse WW, Griffin MR, Gebretsadik T, Shintani AK, Minton PA, Peebles RS, Hamilton R, Weisshaar E, Vrtis R, et al: The relationship of rhinovirus-associated asthma hospitalizations with inhaled corticosteroids and smoking. J Infect Dis 2006, 193(11):1536-1543.
94. Rabinovitch N, Reisdorph N, Silveira L, Gelfand EW: Urinary leukotriene E levels identify children with tobacco smoke exposure at risk for asthma exacerbation. J Allergy Clin Immunol 2011, 128(2):323-327.

95. Fioramonti J, Theodorou V, Bueno L: Probiotics: what are they? What are their effects on gut physiology? Best Pract Res Clin Gastroenterol 2003, 17(5):711-724.

96. Caramia G: Metchnikoff and the centenary of probiotics: an update of their use in gastroenteric pathology during the age of development. Minerva Pediatr 2008, 60(6):1417-1435.

97. Yoo J, Tcheurekdjian H, Lynch SV, Cabana M, Boushey HA: Microbial manipulation of immune function for asthma prevention: inferences from clinical trials. Proc Am Thorac Soc 2007, 4(3):277-282.

98. Wardwell LH, Huttenhower C, Garrett WS: Current concepts of the intestinal microbiota and the pathogenesis of infection. Curr Infect Dis Rep 2011, 13(1):28-34.

99. Borchers AT, Selmi C, Meyers FJ, Keen CL, Gershwin ME: Probiotics and immunity. J Gastroenterol 2009, 44(1):26-46.

100. Vliagoftis H, Kouranos VD, Betsi Gl, Falagas ME: Probiotics for the treatment of allergic rhinitis and asthma: systematic review of randomized controlled trials. Ann Allergy Asthma Immunol 2008, 101(6):570-579.

101. Turnbaugh PJ, Hamady M, Yatsunenko T, Cantarel BL, Duncan A, Ley RE, Sogin ML, Jones WJ, Roe BA, Affourtit JP, et al: A core gut microbiome in obese and lean twins. Nature 2009, 457(7228):480-484.

102. Bisgaard H, Li N, Bonnelykke K, Chawes BL, Skov T, Paludan-Muller G, Stokholm J, Smith B, Krogfelt KA: Reduced diversity of the intestinal microbiota during infancy is associated with increased risk of allergic disease at school age. J Allergy Clin Immunol 2011, 128(3):646-652. e641-645.

103. Round JL, Mazmanian SK: The gut microbiota shapes intestinal immune responses during health and disease. Nat Rev Immunol 2009, 9(5):313-323.

104. Penders J, Thijs C, Vink C, Stelma FF, Snijders B, Kummeling I, van den Brandt PA, Stobberingh EE: Factors influencing the composition of the intestinal microbiota in early infancy. Pediatrics 2006, 118(2):511-521.

105. Adlerberth I, Wold AE: Establishment of the gut microbiota in Western infants. Acta Paediatr 2009, 98(2):229-238.

106. Ege MJ, Mayer M, Normand AC, Genuneit J, Cookson WO, Braun-Fahrlander C, Heederik D, Piarroux R, von Mutius E: Exposure to environmental microorganisms and childhood asthma. N Engl J Med 2011, 364(8):701-709.

107. Ly NP, Litonjua A, Gold DR, Celedon JC: Gut microbiota, probiotics, and vitamin D: interrelated exposures influencing allergy, asthma, and obesity? J Allergy Clin Immunol 2011, 127(5):1087-1094. quiz 1095-1086.

108. Celedon JC, Weiss ST: Use of antibacterials in infancy: clinical implications for childhood asthma and allergies. Treat Respir Med 2004, 3(5):291-294.

109. Forsythe P: Probiotics and lung diseases. Chest 2011, 139(4):901-908.

110. McLoughlin RM, Mills KH: Influence of gastrointestinal commensal bacteria on the immune responses that mediate allergy and asthma. J Allergy Clin Immunol 2011, 127(5):1097-1107. quiz 1108-1099.

111. Issazadeh-Navikas S, Teimer R, Bockermann R: Influence of dietary components on regulatory T cells. Mol Med 2012, 18(1):95-110.

112. Heydarian F, Kianifar HR, Ahanchian H, Khakshure A, Seyedi J, Moshirian D: A comparison between traditional yogurt and probiotic yogurt in noninflammatory acute gastroenteritis. Saudi Med J 2010, 31(3):280-283.

113. Johnston BC, Goldenberg JZ, Vandvik PO, Sun X, Guyatt GH: Probiotics for the prevention of pediatric antibiotic-associated diarrhea. Cochrane Database Syst Rev 2011, (11):CD004827.

114. Wickens K, Black PN, Stanley TV, Mitchell E, Fitzharris P, Tannock GW, Purdie G, Crane J, Probiotic Study G, Green C, et al: A differential effect of 2 probiotics in the prevention of eczema and atopy: a double-blind, randomized, placebo-controlled trial. J Allergy Clin Immunol 2008, 122(4):788-794.

115. Farid $R$, Ahanchian $H$, Jabbari $F$, Moghiman $T$ : Effect of a new synbiotic mixture on atopic dermatitis in children: a randomized-controlled trial. Iran J Pediatr 2011, 21(2):225-230

116. Yao TC, Chang CJ, Hsu YH, Huang JL: Probiotics for allergic diseases: realities and myths. Pediatr Allergy Immunol 2010, 21(6):900-919.

117. Izumo T, Maekawa T, Ida M, Noguchi A, Kitagawa Y, Shibata H, Yasui H, Kiso Y: Effect of intranasal administration of Lactobacillus pentosus S-PT84 on influenza virus infection in mice. Int Immunopharmacol 2010, 10(9):1101-1106.

118. Hojsak I, Snovak N, Abdovic S, Szajewska H, Misak Z, Kolacek S: Lactobacillus GG in the prevention of gastrointestinal and respiratory 
tract infections in children who attend day care centers: a randomized, double-blind, placebo-controlled trial. Clin Nutr 2010, 29(3):312-316.

119. Morrow LE, Kollef MH, Casale TB: Probiotic prophylaxis of ventilatorassociated pneumonia a blinded, randomized, controlled trial. Am $\lrcorner$ Respir Crit Care Med 2010, 182(8):1058-1064.

120. Hatakka K, Savilahti E, Ponka A, Meurman JH, Poussa T, Nase L, Saxelin M, Korpela R: Effect of long term consumption of probiotic milk on infections in children attending day care centres: double blind, randomised trial. Brit Med J 2001, 322(7298):1327-1329.

121. Hojsak I, Abdovic S, Szajewska H, Milosevic M, Krznaric Z, Kolacek S: Lactobacillus GG in the prevention of nosocomial gastrointestinal and respiratory tract infections. Pediatrics 2010, 125(5):E1171-E1177.

122. de Vrese M, Winkler P, Rautenberg P, Harder T, Noah C, Laue C, Ott S, Hampe J, Schreiber $S$, Heller $K$, et al: Probiotic bacteria reduced duration and severity but not the incidence of common cold episodes in a double blind, randomized, controlled trial. Vaccine 2006, 24(44-46):6670-6674.

123. Leyer GJ, Li SG, Mubasher ME, Reifer C, Ouwehand AC: Probiotic effects on cold and influenza-like symptom incidence and duration in children. Pediatrics 2009, 124(2):E172-E179.

124. Winkler $P$, de Vrese M, Laue C, Schrezenmeir J: Effect of a dietary supplement containing probiotic bacteria plus vitamins and minerals on common cold infections and cellular immune parameters. Int J Clin Pharm Th 2005, 43(7):318-326.

125. Hao Q, Lu Z, Dong BR, Huang CQ, Wu T: Probiotics for preventing acute upper respiratory tract infections. Cochrane Database Syst Rev 2011, 9:CD006895.

126. Makino S, Ikegami S, Kume A, Horiuchi H, Sasaki H, Orii N: Reducing the risk of infection in the elderly by dietary intake of yoghurt fermented with Lactobacillus delbrueckii ssp. bulgaricus OLL1073R-1. Br J Nutr 2010, 104(7):998-1006

127. Meydani SN, Ha WK: Immunologic effects of yogurt. Am J Clin Nutr 2000, 71(4):861-872

128. Merenstein D, Murphy M, Fokar A, Hernandez RK, Park H, Nsouli H, Sanders ME, Davis BA, Niborski V, Tondu F, et al: Use of a fermented dairy probiotic drink containing Lactobacillus casei (DN-114 001) to decrease the rate of illness in kids: the DRINK study. A patient-oriented, double-blind, cluster-randomized, placebo-controlled, clinical trial. Eur J Clin Nutr 2010, 64(7):669-677.

129. de Moreno de LeBlanc A, Chaves S, Carmuega E, Weill R, Antoine J, Perdigon G: Effect of long-term continuous consumption of fermented milk containing probiotic bacteria on mucosal immunity and the activity of peritoneal macrophages. Immunobiology 2008, 213(2):97-108.

130. Ares G, Gimenez A, Gambaro A: Influence of nutritional knowledge on perceived healthiness and willingness to try functional foods. Appetite 2008, 51(3):663-668.

131. Holzapfel WH, Haberer P, Geisen R, Bjorkroth J, Schillinger U: Taxonomy and important features of probiotic microorganisms in food and nutrition. Am J Clin Nutr 2001, 73(2 Suppl):365S-373S.

132. Lomax AR, Calder PC: Prebiotics, immune function, infection and inflammation: a review of the evidence. Br J Nutr 2009, 101(5):633-658.

133. Kukkonen K, Savilahti E, Haahtela T, Juntunen-Backman K, Korpela R, Poussa T, Tuure T, Kuitunen M: Long-term safety and impact on infection rates of postnatal probiotic and prebiotic (synbiotic) treatment: randomized, double-blind, placebo-controlled trial. Pediatrics 2008, 122(1):8-12

134. Rose MA, Stieglitz F, Koksal A, Schubert R, Schulze J, Zielen S: Efficacy of probiotic Lactobacillus GG on allergic sensitization and asthma in infants at risk. Clin Exp Allergy 2010, 40(9):1398-1405.

135. Del-Rio-Navarro BE, Espinosa Rosales F, Flenady V, Sienra-Monge JJ: Immunostimulants for preventing respiratory tract infection in children. Cochrane Database Syst Rev 2006, (4):CD004974.

136. Weinberger M: Can we prevent exacerbations of asthma caused by common cold viruses? J Allergy Clin Immunol 2010, 126(4):770-771

137. Schaad UB: OM-85 BV, an immunostimulant in pediatric recurrent respiratory tract infections: a systematic review. World J Pediatr 2010, 6(1):5-12.

138. Razi CH, Harmanci K, Abaci A, Ozdemir O, Hizli S, Renda R, Keskin F: The immunostimulant OM-85 BV prevents wheezing attacks in preschool children. J Allergy Clin Immunol 2010, 126(4):763-769.

139. Strickland DH, Judd S, Thomas JA, Larcombe AN, Sly PD, Holt PG: Boosting airway T-regulatory cells by gastrointestinal stimulation as a strategy for asthma control. Mucosal Immunol 2011, 4(1):43-52
140. Rozy A, Chorostowska-Wynimko J: Bacterial immunostimulantsmechanism of action and clinical application in respiratory diseases. Pneumonol Alergol Pol 2008, 76(5):353-359.

141. Holgate ST: Epithelium dysfunction in asthma. J Allergy Clin Immunol 2007, 120(6):1233-1244. quiz 1245-1236.

142. Proud D: Role of rhinovirus infections in asthma. Asian Pac J Allergy Immunol 2011, 29(3):201-208.

143. Koltsida O, Hausding M, Stavropoulos A, Koch S, Tzelepis G, Ubel C, Kotenko SV, Sideras P, Lehr HA, Tepe M, et al: IL-28A (IFN-lambda2) modulates lung DC function to promote Th1 immune skewing and suppress allergic airway disease. EMBO Mol Med 2011, 3(6):348-361.

144. Farr BM, Gwaltney JM, Adams KF, Hayden FG: Intranasal interferon-alpha-2 for prevention of natural rhinovirus colds. Antimicrob Agents Chemother 1984, 26(1):31-34.

145. Higgins PG, Alnakib W, Willman J, Tyrrell DAJ: Interferon-beta-ser as prophylaxis against experimental rhinovirus infection in volunteers. J Interferon Res 1986, 6(2):153-159.

146. Phillpotts RJ, Scott GM, Higgins PG, Wallace J, Tyrrell DAJ, Gauci CL: An effective dosage regimen for prophylaxis against rhinovirus infection by Intranasal Administration of Huifn-Alpha-2. Antiviral Res 1983, 3(2):121-136.

147. Miller EK, Hernandez JZ, Wimmenauer V, Shepherd BE, Hijano D, Libster R, Serra ME, Bhat N, Batalle JP, Mohamed Y, et al: A mechanistic role for type III Interferon-lambda1 in asthma exacerbations mediated by human rhinoviruses. Am J Respir Crit Care Med 2011, 185(5):508-516.

148. Edwards MR, Johnston SL: Interferon-lambda as a new approach for treatment of allergic asthma? EMBO Mol Med 2011, 3(6):306-308.

149. Holick MF: Vitamin D deficiency. N Engl J Med 2007, 357(3):266-281.

150. Holick MF: High prevalence of vitamin D inadequacy and implications for health. Mayo Clin Proc 2006, 81(3):353-373.

151. Paul G, Brehm JM, Alcorn JF, Holguin F, Aujla SJ, Celedon JC: Vitamin D and asthma. Am J Respir Crit Care Med 2012, 185(2):124-132.

152. Biesalski HK: Vitamin D recommendations: beyond deficiency. Ann Nutr Metab 2011, 59(1):10-16.

153. Yim S, Dhawan P, Ragunath C, Christakos S, Diamond G: Induction of cathelicidin in normal and CF bronchial epithelial cells by 1,25-dihydroxyvitamin D(3). J Cyst Fibros 2007, 6(6):403-410.

154. Hansdottir S, Monick MM, Hinde SL, Lovan N, Look DC, Hunninghake GW: Respiratory epithelial cells convert inactive vitamin $D$ to its active form: potential effects on host defense. J Immuno/ 2008, 181(10):7090-7099.

155. Vassallo MF, Camargo CA Jr: Potential mechanisms for the hypothesized link between sunshine, vitamin $D$, and food allergy in children. J Allergy Clin Immunol 2010, 126(2):217-222.

156. Camargo CA Jr, Clark S, Kaplan MS, Lieberman P, Wood RA: Regional differences in EpiPen prescriptions in the United States: the potential role of vitamin D. J Allergy Clin Immunol 2007, 120(1):131-136.

157. Osborne NJ, Ukoumunne OC, Wake M, Allen KJ: Prevalence of eczema and food allergy is associated with latitude in Australia. J Allergy Clin Immunol 2012, 129(3):865-867.

158. Ginde AA, Mansbach JM, Camargo CA Jr: Vitamin D, respiratory infections, and asthma. Curr Allergy Asthma Rep 2009, 9(1):81-87.

159. Black PN, Scragg R: Relationship between serum 25-hydroxyvitamin D and pulmonary function in the third national health and nutrition examination survey. Chest 2005, 128(6):3792-3798.

160. Jartti T, Ruuskanen O, Mansbach JM, Vuorinen T, Camargo CA Jr: Low serum 25-hydroxyvitamin D levels are associated with increased risk of viral coinfections in wheezing children. J Allergy Clin Immunol 2010, 126(5):1074-1076. 1076 e1071-1074

161. Majak P, Olszowiec-Chlebna M, Smejda K, Stelmach I: Vitamin D supplementation in children may prevent asthma exacerbation triggered by acute respiratory infection. J Allergy Clin Immunol 2011, 127(5):1294-1296.

162. Hernando-Sastre V: Macrolide antibiotics in the treatment of asthma. An update. Allergol Immunopathol (Madr) 2010, 38(2):92-98.

163. Jaffe A, Bush A: Anti-inflammatory effects of macrolides in lung disease. Pediatr Pulmonol 2001, 31(6):464-473.

164. Good JT Jr, Rollins DR, Martin RJ: Macrolides in the treatment of asthma. Curr Opin Pulm Med 2012, 18(1):76-84

165. Lin SJ, Lee WJ, Liang YW, Yan DC, Cheng PJ, Kuo ML: Azithromycin inhibits IL-5 production of T helper type 2 cells from asthmatic children. Int Arch Allergy Immunol 2011, 156(2):179-186. 
166. Johnston SL: Macrolide antibiotics and asthma treatment. J Allergy Clin Immunol 2006, 117(6):1233-1236.

167. Gielen V, Johnston SL, Edwards MR: Azithromycin induces anti-viral responses in bronchial epithelial cells. Eur Respir J 2010, 36(3):646-654

168. Asada M, Yoshida M, Suzuki T, Hatachi Y, Sasaki T, Yasuda H, Nakayama K, Nishimura $\mathrm{H}$, Nagatomi $\mathrm{R}$, Kubo $\mathrm{H}$, et al: Macrolide antibiotics inhibit respiratory syncytial virus infection in human airway epithelial cells. Antiviral Res 2009, 83(2):191-200.

169. Tahan F, Ozcan A, Koc N: Clarithromycin in the treatment of RSV bronchiolitis: a double-blind, randomised, placebo-controlled trial. Eur Respir J 2007, 29(1):91-97.

170. Miller EK, Edwards KM, Weinberg GA, Iwane MK, Griffin MR, Hall CB, Zhu Y, Szilagyi PG, Morin LL, Heil LH, et al: A novel group of rhinoviruses is associated with asthma hospitalizations. J Allergy Clin Immunol 2009, 123(1):98-104 e101.

171. Khetsuriani N, Lu X, Teague WG, Kazerouni N, Anderson LJ, Erdman DD: Novel human rhinoviruses and exacerbation of asthma in children. Emerg Infect Dis 2008, 14(11):1793-1796.

172. Harris JM 2nd, Gwaltney JM Jr: Incubation periods of experimental rhinovirus infection and illness. Clinical infectious diseases: an official publication of the Infectious Diseases Society of America 1996, 23(6):1287-1290

173. Staunton DE, Merluzzi VJ, Rothlein R, Barton R, Marlin SD, Springer TA: A cell adhesion molecule, ICAM-1, is the major surface receptor for rhinoviruses. Cell 1989, 56(5):849-853.

174. Hofer F, Gruenberger M, Kowalski H, Machat H, Huettinger M, Kuechler E, Blaas D: Members of the low density lipoprotein receptor family mediate cell entry of a minor-group common cold virus. Proc Natl Acad Sci U S A 1994, 91(5):1839-1842.

175. Rankl C, Kienberger F, Wildling L, Wruss J, Gruber HJ, Blaas D, Hinterdorfer P: Multiple receptors involved in human rhinovirus attachment to live cells. Proc Natl Acad Sci U S A 2008, 105(46):17778-17783.

176. Jang YJ, Wang JH, Kim JS, Kwon HJ, Yeo NK, Lee BJ: Levocetirizine inhibits rhinovirus-induced ICAM-1 and cytokine expression and viral replication in airway epithelial cells. Antiviral Res 2009, 81(3):226-233.

177. Prasad AS, Beck FW, Bao B, Snell D, Fitzgerald JT: Duration and severity of symptoms and levels of plasma interleukin-1 receptor antagonist, soluble tumor necrosis factor receptor, and adhesion molecules in patients with common cold treated with zinc acetate. J Infect Dis 2008, 197(6):795-802.

178. Fang F, Yu M: Viral receptor blockage by multivalent recombinant antibody fusion proteins: inhibiting human rhinovirus (HRV) infection with CFY196. J Antimicrob Chemother 2004, 53(1):23-25.

179. Turner RB, Wecker MT, Pohl G, Witek TJ, McNally E, St George R, Winther B, Hayden FG: Efficacy of tremacamra, a soluble intercellular adhesion molecule 1, for experimental rhinovirus infection - a randomized clinical trial. Jama-J Am Med Assoc 1999, 281(19):1797-1804.

180. Thibaut HJ, De Palma AM, Neyts J: Combating enterovirus replication: stateof-the-art on antiviral research. Biochem Pharmacol 2012, 83(2):185-192.

181. Hayden FG, Turner RB, Gwaltney JM, Chi-Burris K, Gersten M, Hsyu P, Patick AK, Smith GJ, Zalman LS: Phase II, randomized, double-blind, placebo-controlled studies of ruprintrivir nasal spray 2-percent suspension for prevention and treatment of experimentally induced rhinovirus colds in healthy volunteers. Antimicrob Agents Chemother 2003, 47(12):3907-3916.

182. Schubert S, Furste JP, Werk D, Grunert HP, Zeichhardt H, Erdmann VA, Kurreck J: Gaining target access for deoxyribozymes. J Mol Biol 2004 339(2):355-363.

183. Stone JK, Rijnbrand R, Stein DA, Ma Y, Yang Y, Iversen PL, Andino R: A morpholino oligomer targeting highly conserved internal ribosome entry site sequence is able to inhibit multiple species of picornavirus. Antimicrob Agents Chemother 2008, 52(6):1970-1981.

184. Phipps KM, Martinez A, Lu J, Heinz BA, Zhao G: Small interfering RNA molecules as potential anti-human rhinovirus agents: in vitro potency, specificity, and mechanism. Antiviral Res 2004, 61(1):49-55.

185. Stensballe LG, Ravn H, Kristensen K, Agerskov K, Meakins T, Aaby P, Simoes EA: Respiratory syncytial virus neutralizing antibodies in cord blood, respiratory syncytial virus hospitalization, and recurrent wheeze. J Allergy Clin Immunol 2009, 123(2):398-403.

186. Hansbro NG, Horvat JC, Wark PA, Hansbro PM: Understanding the mechanisms of viral induced asthma: new therapeutic directions. Pharmacol Ther 2008, 117(3):313-353.
187. Simoes EA, Groothuis JR, Carbonell-Estrany X, Rieger CH, Mitchell I, Fredrick LM, Kimpen JL: Palivizumab prophylaxis, respiratory syncytial virus, and subsequent recurrent wheezing. J Pediatr 2007, 151(1):34-42. 42 e31.

188. Wu H, Pfarr DS, Johnson S, Brewah YA, Woods RM, Patel NK, White WI, Young JF, Kiener PA: Development of motavizumab, an ultra-potent antibody for the prevention of respiratory syncytial virus infection in the upper and lower respiratory tract. J Mol Biol 2007, 368(3):652-665.

189. Shadman KA, Wald ER: A review of palivizumab and emerging therapies for respiratory syncytial virus. Expert Opin Biol Ther 2011, 11(11):1455-1467.

190. Carbonell-Estrany X, Simoes EA, Dagan R, Hall CB, Harris B, Hultquist M, Connor EM, Losonsky GA: Motavizumab for prophylaxis of respiratory syncytial virus in high-risk children: a noninferiority trial. Pediatrics 2010 125(1):e35-e51.

191. Bardin PG: Vaccination for asthma exacerbations. Intern Med J 2004, 34(6):358-360

192. Rosenthal LA, Avila PC, Heymann PW, Martin RJ, Miller EK, Papadopoulos NG, Peebles RS, Gern JE, Immunol AAAA: Viral respiratory tract infections and asthma: the course ahead. J Allergy Clin Immun 2010, 125(6):1212-1217.

193. Bizzintino J, Lee WM, Laing IA, Vang F, Pappas T, Zhang G, Martin AC, Khoo SK, Cox DW, Geelhoed GC, et al: Association between human rhinovirus $C$ and severity of acute asthma in children. Eur Respir J 2011, 37(5):1037-1042

\section{doi:10.1186/1471-2431-12-147}

Cite this article as: Ahanchian et al:: Respiratory viral infections in children with asthma: do they matter and can we prevent them? BMC Pediatrics 2012 12:147.

\section{Submit your next manuscript to BioMed Central and take full advantage of:}

- Convenient online submission

- Thorough peer review

- No space constraints or color figure charges

- Immediate publication on acceptance

- Inclusion in PubMed, CAS, Scopus and Google Scholar

- Research which is freely available for redistribution 